\title{
Fuel Qualities and Combustion Characteristics of Animal-Fats Biodiesel for Agricultural Hot Air Heaters
}

\author{
Youngjung Kim*, Seokho Park, Youngin Kim, Chungkil Kim \\ Energy \& Environmental Engineering Division, National Academy of Agricultural Science, Suwon, Korea \\ Received: July $26^{\text {th }}, 2012$; Revised: October $25^{\text {th }}, 2012$; Accepted: October $25^{\text {th }}, 2012$
}

\section{Abstract}

Purpose: Combustion and fuel qualities of the animal-fats biodiesel as a heating fuel for agricultural hot air heater were studied. Methods: Biodiesel (BD) was made from animal-fats by reacting with methanol and potassium hydroxide in the laboratory. The biodiesel made in the laboratory was tested for fuel and combustion qualities. Results: The kinematic viscosity and the calorific values of the biodiesels were measured. Kerosene based biodiesel, BD20 (K) showed $18 \mathrm{cSt}$ at $-20^{\circ} \mathrm{C}$. It seemed that BD100 was not suitable for a heating fuel under some temperature. As BD content increased, the calorific value decreased up to 40,000 J/g for BD100, while the calorific value of light oil was 45,567 J/g showing difference of 5,567 J/g, about 12\% difference. Several different fuels including BD20 (biodiesel 20\% + light oil 80\%), BD50 (biodiesel $50 \%+$ light oil 50\%), BD100 (biodiesel 100\%), and light oil were tested for fuel combustion qualities for agricultural hot air heater, and their combustion performances were compared and analyzed. Flame dimensions of biodiesels and light oils were almost the same shape at the same combustion condition. Generally, the $\mathrm{CO}_{2}$ amounts of BDs were greater than light oil. However, in this study the differences were minor, so there was no significant difference existed between the BDs combustion and light oil. Conclusions: It seemed that quality was good for heating oil for agricultural hot air heater because of showing no barriers for continuous combustion and proper exhaust gas temperature and $\mathrm{CO}_{2}$ amount discharged. But, for fuel fluidity for higher BD content fuel could be a detrimental problem in situations where the outdoor temperature is lowered. As BD content increased, calorific value decreased up to 40,000 J/g for BD100. Calorific value difference between BD20 and light oil was about $1,360 \mathrm{~J} / \mathrm{g}$.

Keywords: Animal-fats, Biodiesel, Combustion, Fuel qualities, Hot air heater

\section{Introduction}

Recently, biodiesel is used in northern European countries and North America as a heating fuel or transportation fuel. It is reported that $100 \%$ BD (BD100) is used for metro bus fuel and construction machinery fuel in the developed countries (Wilson, 2003; Hofman, 2003). Germany introduced diesel engine to run on soybean oil. However, due to the low cost of mineral oils at the time, the diesel engine was modified to run on petroleum oil. Since then light oil has been regarded as a fuel for diesel engines. As the prices of fossil fuels have been increased recently, the

\footnotetext{
*Comesponding author: Youngjung Kim

Tel: +82-31-290-1828; Fax: +82-31-290-1840

E-mail: kim0yoj@korea.kr
}

demand for alternative fuels such as oil crops biodiesel or bioehtanol also has grown.

Biodiesel is known for providing better combustible condition in diesel engines. It has two more oxygen molecular than light oil, contributing 11\% more oxygen amount in weight basis than light oil when it is combusting in the engine chamber. It is also known that less toxic exhaust gases are produced by biodiesel combustion in diesel engine than that of light oil. According to Lee's study (2004), internal diesel engines combusting $20 \%$ biodiesel discharged polluted matters 20\% less, carbon monoxide $12 \%$ less, fine dust $12 \%$ less, $\mathrm{NO}_{\mathrm{x}} 2 \%$ more, $\mathrm{SO}_{\mathrm{X}} 20 \%$ less and aromatic chemicals $13 \%$ less than those with light oil. The increase of NOx discharge is caused by higher oxygen content in biodiesel than one in 
light oil. When the biodiesel was used for agricultural tractor, the operations such as tilling and plowing were required $30-40 \%$ more biodiesel than light oil (Kim et al., 2010). However, the troubles such as no ignition or abrupt stopping were not monitored during the works of plowing, rotary tilling and travelling on the road. Pour points of the biodiesels were higher than light oil, and when biodiesel content ratio increased, pour point increased. Kinematic viscosity of $15 \mathrm{cSt}$ was found at $3-4^{\circ} \mathrm{C}$ for biodiesels and at $-25^{\circ} \mathrm{C}$ for light oil (Kim et al., 2008). Biodiesel is also coming from animal-fats. In Korea, about 400 thousand tons of animal-fats are produced annually, and these can be transformed to biodiesel of 315 thousand $\mathrm{kl}$, which is equivalent to $25 \%$ of fuel consumption amount $(1,264$ thousand $\mathrm{kl})$ used in protected crops production industry (Korea Institute of Energy Research, 2011). Cow and swine fats are the main resources for animal-fats biodiesel production. Animal-fats biodiesel produced in the USA was about 450 million litres in 2008 that was taken up $20 \%$ of the total biodiesel production amount in 2008 (Goodfellow, 2010). Biodiesel can be an alternative fuel for a heating fuel in the hot air heaters for greenhouse heating. Several studies have been conducted on the combustion characteristics for hot air heater. Spraying and combustion characteristics of heavy oil in the gun type burner were defined (Kim et al., 1999), and various combustion experiments to determine flame size and exhaust gases for the gun type burner combusting waste tire oil were carried out in the hot air heater (Kim et al., 2000). According to Kim et al., (1999; 2000) oil temperature and spraying pressure in the fuel pump and airflow rate in the blower were critical factors in making complete combustion in the combustion chamber of the hot air heater. The objective of this study is to evaluate the combustion quality of animal-fats biodiesel and investigate physical properties of animal-fats biodiesel related to fuel characteristics.

\section{Material and Methods}

\section{Preparation of animal-fats biodiesel}

Figure 1 shows processes of biodiesel production from animal-fats. Four major steps are required to transform animal-fats into biodiesel; material preparation, oil extraction, potassium methoxide reaction, washing and drying.

In the preparation stage, an extruder was used to adjust the size of animal-fats, and then they were melted in a microwave oven for 20 to 30 minutes depending on the amount of animal-fats in order to get oil. This oil is ready to react with a catalyst, potassium methoxide, mixed of methanol and potassium, of which methanol amount is $25 \%$ of the fats in weight basis and potassium hydroxide amount is $0.5 \%$ of the fats in weight basis. Methoxide reaction lasted about two hours at $60^{\circ} \mathrm{C}$. The reaction took one hour stirring and one hour resting which made them separate the glycerine at the top and raw biodiesel at the bottom. After water washing cleaned the impurities in the raw biodiesel, $30 \%$ of biodiesel amount of water was added at $40^{\circ} \mathrm{C}$ with 5 minutes stirring and 20 minutes resting. Double water washing was required to remove all impurities. Final step was that dries up the water which remained in the biodiesel after water washing process. After stirring for 30 minutes at lower rpm and resting for 20 minutes at $60^{\circ} \mathrm{C}$, the biodiesel became clear. Two times of drying operation was needed to obtain high quality biodiesel. The method we adopted was common biodiesel production process except the extruder sizing, oil extraction in a microwave oven heating, and using of potassium hydroxide instead of sodium hydroxide in methoxide reaction recipe. All the processes were done by manual works. And, the final biodiesel was quite good to use for a heating fuel in the agricultural hot air heater.

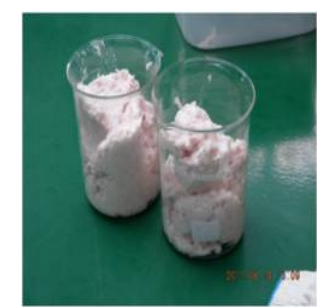

Preparation

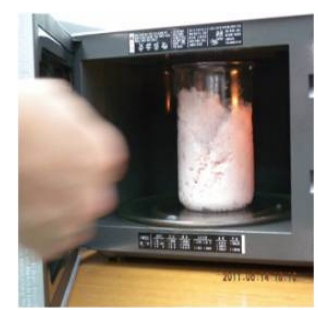

heating in the microwave oven

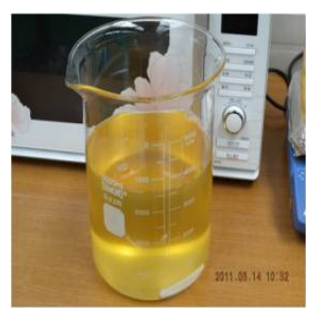

pig oil

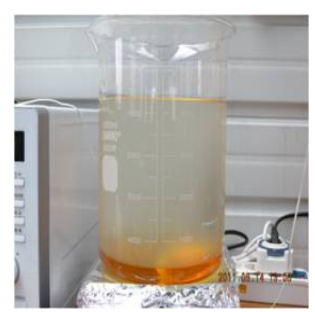

methoxide reaction process

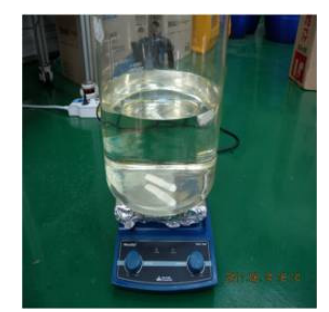

after washing and drying process

Figure 1. Manufacturing processes for pig fats biodiesel. 


\section{Fuel preparation}

Three different fuels, animal-fats biodiesel 20\% (BD20), animal-fats biodiesel 100\% (BD100) and light oil were prepared for this study. BDs were transformed from pig-fats after the transesterification process. Upon animalfats, several pretreatments such as unfreezing and fat size adjustment were required before they were placed in a micro-oven for oil extracting. As there is no established oil extracting process from animal-fats, all the oils for producing biodiesel was made by hands. For biodiesel quality inspection the biodiesel manufactured was sent to Korean Petroleum Quality Inspection Agency and the test results were reported in the Results and Discussion section.

\section{Properties of animal-fat biodiesel}

The caloric values of various fuels were measured with calorimeter (IKA-CAL2K). The kinematic viscosity of the biodiesel was measured by using viscometer (Brookfield DV- II, Brookfield Engineering Laboratories). Measurement temperature ranges were from -20 to $40^{\circ} \mathrm{C}$ at $10^{\circ} \mathrm{C}$ intervals. For the viscosity measurement, two different kinds of biodiesel were prepared; light oil based biodiesel and kerosene based biodiesel. Therefore, BD20 (L) was considered as light oil based biodiesel and BD50 (K) was considered as kerosene based biodiesel. Figure 2 shows the measuring devices for this study.

\section{Combustion test}

For investigating combustion qualities of different BD fuels in a hot air heater, several kinds of BD were tested for their combustion performances and their performance characteristics were determined by comparing the kind of exhaust gas and their temperatures including hot air temperatures produced by the hot air heater. The hot air heater which has gun type burner with a spraying nozzle (Hago, 4.0 gallons $/ \mathrm{hr}, 60^{\circ}$, hollow cone type) consumed $20 \ell$ of light oil per hour. An exhaust gas analyzer (Greenline Mk2, eurotron) was used for the analysis of exhausted gas. For combustion test in the hot air heater (Figure 3) flame size (diameter and length) were measured by photo analysis and exhaust gas analysis was conducted as in the previous studies (Kim et al., 1999; Kim et al., 2000).

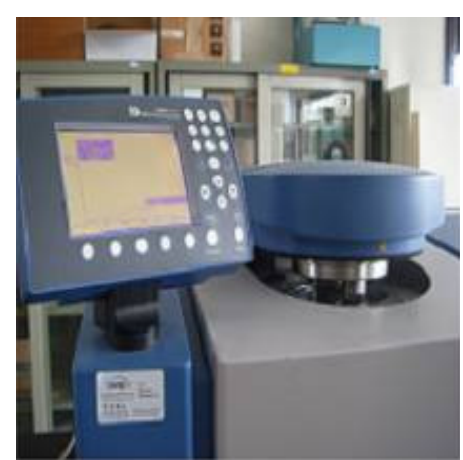

Calorimeter

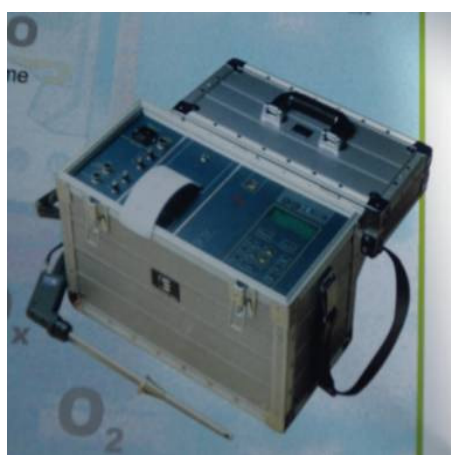

Gas analyzer

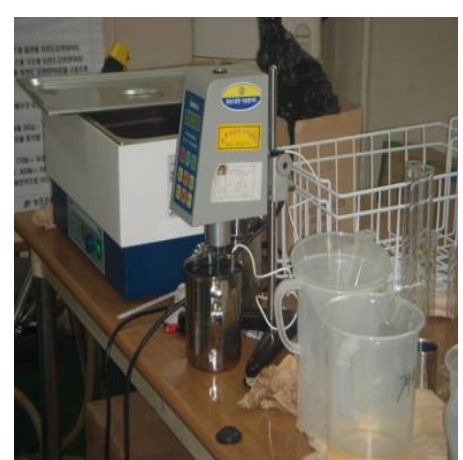

Viscometer

Figure 2. Calorimeter, exhaust gas analyzer, and viscometer.
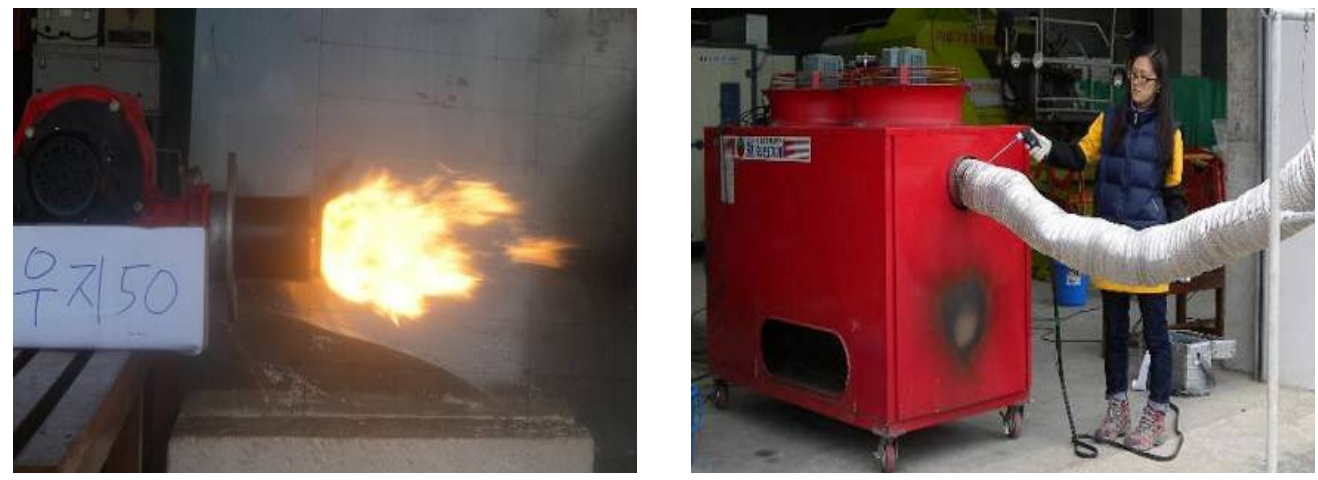

Figure 3. Scenes of flame size measurement and exhaust gas analysis. 


\section{Results and Discussion}

\section{Quality of animal-fats biodiesel}

The biodiesel we made was sent to Korea Institute of Petroleum Management (K Petro) to inspect its quality. The specifications of the animal-fats biodiesel and BD were compared in Table 1 , and the table shows the quality of the biodiesel we made. FAME (Fatty Acid Methyl Easter) amount was not good enough to satisfy K Petro FAME standard of BD100. However, flash point, kinematic viscosity, carbon residue, ash amount, density and leftover methanol amount were under the $\mathrm{K}$ Petro specifications. Total glycerol and oxidation stability were not quite directly relevant to the heating fuel for agricultural hot air heater. Therefore, we assumed that animal-fats biodiesel could not be a problem for a heating fuel substituting for kerosene or light oil. Moreover, the biodiesel is usually mixed with light oil or kerosene with radios of 5\%, $20 \%$ and $50 \%$. Normally, $100 \%$ biodiesel is not used in real situation because of shortage of fuel fluidity. However, some countries such as Italy, Germany, Sweden, and other EU countries use $100 \%$ biodiesel for a heating fuel.

\section{Calorific values of various biodiesels}

The calorific values of several BDs mixed with light oil were shown in Figure 4. As BD content increased, the calorific value decreased up to $40,000 \mathrm{~J} / \mathrm{g}$ for BD100, while calorific value of light oil was 45,567 J/g showing difference of 5,567 J/g, about $12 \%$ difference. The calorific value difference between BD20 and light oil was about $1,360 \mathrm{~J} / \mathrm{g}$, i.e., the calorific value of BD20 was only $3 \%$ lower than that of light oil.

\section{Kinematic viscosities of the biodiesels}

Figure 5 shows the kinematic viscosities of animal-fats biodiesel mixed with light oil and kerosene according to mixing ratio and temperature. The kinematic viscosity is the critical factor in combustion mechanisim. In general,

Table 1. Specifications of the animal-fats based biodiesel

\begin{tabular}{|cccc}
\hline Property & Animal-fats biodiesel-BD100 & BD100 quality defined by Kpetro & Remark \\
\hline FAME $($ vol, $\%)$ & 95.5 & Over 96.5 & Not good \\
\hline Flash point $\left({ }^{\circ} \mathrm{C}\right)$ & 180.5 & Over 129 & good \\
\hline Kin. Viscosity $\left(40^{\circ} \mathrm{C}, \mathrm{mm}^{2} / \mathrm{s}\right)$ & 4.945 & $1.9 \sim 5.0$ & good \\
\hline Carbon residue $(\mathrm{wt}, \%)$ & 0.01 & Below 0.1 & good \\
\hline Sulfur $(\mathrm{mg} / \mathrm{kg})$ & 4 & Below 10 & good \\
\hline Ash $(\mathrm{wt} \%)$ & Below 0.01 & good \\
\hline Density $\left(15^{\circ} \mathrm{C}, \mathrm{kg} / \mathrm{m}^{3}\right)$ & 8.009 & $860 \sim 900$ & good \\
\hline Total glycerol $(\mathrm{wt}, \%)$ & 0.39 & Below 0.24 & Not good \\
\hline Oxidation stability $\left(110^{\circ} \mathrm{C}\right)$ & 1.3 & Over 6 & Not good \\
\hline Methanol $(\mathrm{wt}, \%)$ & 0.01 or less & Below 0.2 & good \\
\hline
\end{tabular}

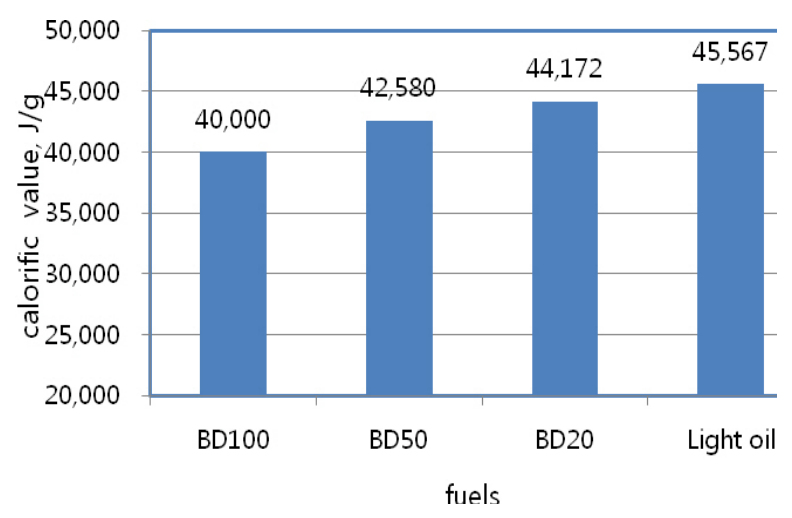

Figure 4. Calorific values of animal-fats biodiesel according to mixing ratio with light oil.

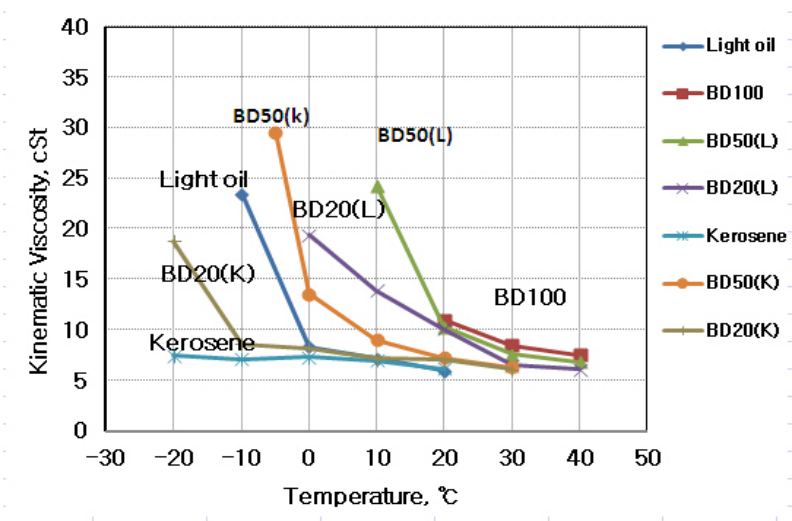

Figure 5. Kinematic viscosities of various BD by different temperatures. 
when temperature drops, the kinematic viscosity of fuel increases. According to the Figure 5, the fluidity of kerosene was the best because it maintained $7 \mathrm{cSt}$ at $-20^{\circ} \mathrm{C}$. BD20 (K) showed the next best mobility as it showed $18 \mathrm{cSt}$ at $-20^{\circ} \mathrm{C}$. However, it seems that BD100 is not suitable for a heating fuel under some temperatures. BD100 is rarely used though some countries use BD100 for a heating fuel stroed in the indoors. BD for engine fuel is different story because fuel supplying and combustion in the internal engines are far more complicated than those of the burner. Many studies (Ministry of Agriculture and Forestry, 2006; Prankl et al., 2006; Choi et al., 2007) have been conducted on the effects of biodiesel on the internal engines. BD5 was good enough for fuel spraying through the nozzle and no damage on the nozzle durability in a long term operation, however, BD20 used in engines for long term use caused some coke deposits in the piston head.

\section{Combustion test}

Total four combustion tests with various BDs were performed at the same condition of spraying pressure $980 \mathrm{kPa}$ and air flow rate $11.47 \mathrm{~m}^{3} / \mathrm{min}$.

Flame size of BDs combustion was not quite different among the four flames ranging from $180 \times 450$ to $180 \times$ $500 \mathrm{~mm}$, and the shapes of all flames were similar (Table 2). However, flame colors were somewhat different with naked eyes; they varied from bright orange to yellowish orange depending on the BD content. As BD content increased, the flame color became more yellowish orange. Combustion characteristics were very similar, and exhaust gas temperature varied from $342^{\circ} \mathrm{C}$ of light oil to $365^{\circ} \mathrm{C}$ of BD20. Since BD has $11 \%$ more oxygen, generally, it is known that BD combustion performance is better than light oil. Thus, generally the $\mathrm{CO}_{2}$ amounts of BDs were greater than light oil as in Table 2. However, the differences were minor, so there was no significant difference existed between the BDs combustion and light oil.

\section{Conclusions}

Animal-fats based biodiesel was made manually in the laboratory. Quality of the biodiesel was inspected; FAME (Fatty Acid Methyl Easter) amount was not good enough to satisfy K Petro FAME standard of BD100. However, flash point, kinematic viscosity, carbon residue, ash amount, density, and remained methanol amount satisfied the specifications of the K Petro. In general, it seemed that quality was good for heating oil for agricultural hot air heater because of showing no barriers for continuous combustion and proper exhaust gas temperature and $\mathrm{CO}_{2}$ amount discharged. But, for fuel fluidity for higher BD

Table 2. Flames sizes and combustion characteristics of biodiesels

\begin{tabular}{|c|c|c|c|}
\hline Fuel & Flame shape & Dimension $(\Phi \times \mathrm{L}(\mathrm{mm}))$ & Combustion characteristics \\
\hline Light oil & & $180 \times 500$ & $\begin{array}{l}\mathrm{CO}_{2}(\%): 10.1 \\
\mathrm{GT}\left({ }^{\circ} \mathrm{C}\right): 342 \\
\mathrm{CE}(\%): 81.1\end{array}$ \\
\hline BD5 & & $180 \times 500$ & $\begin{array}{l}\mathrm{CO}_{2}(\%): 9.9 \\
\mathrm{GT}\left({ }^{\circ} \mathrm{C}\right): 343 \\
\mathrm{CE}(\%): 80.7\end{array}$ \\
\hline BD20 & & $180 \times 500$ & $\begin{array}{l}\mathrm{CO}_{2}(\%): 9.8 \\
\mathrm{GT}\left({ }^{\circ} \mathrm{C}\right): 365 \\
\mathrm{CE}(\%): 79.2\end{array}$ \\
\hline BD50 & & $180 \times 450$ & $\begin{array}{l}\mathrm{CO}_{2}(\%): 10.3 \\
\mathrm{GT}\left({ }^{\circ} \mathrm{C}\right): 360 \\
\mathrm{CE}(\%): 80.6\end{array}$ \\
\hline
\end{tabular}

GT $\left({ }^{\circ} \mathrm{C}\right)$ : Gas temperature, CE (\%): Combustion efficiency 
content fuel could be a detrimental problem in situations where the outdoor temperature is lowered. As BD content increased, the calorific value decreased up to $40,000 \mathrm{~J} / \mathrm{g}$ for BD100. The calorific value difference between BD20 and light oil was about $1,360 \mathrm{~J} / \mathrm{g}$.

\section{Conflict of Interest}

No potential conflict of interest relevant to this article was reported.

\section{Acknowledgments}

This study was carried out with the support of "Research Program for Agricultural Science \& Technology Development (Project No.PJ006461)", National Academy of Agricultural Science, Rural Development Administration, Republic of Korea.

\section{References}

Choi, S. H., Y. T. Oh and G. H. Kim. 2007. Characteristics of durability and emission with biodiesel fuel (5\%) in a common rail direct injection engine at seoul-10 mode. Journal of Biosystems Engineering 32:97-101 (In Korean, with English abstract).

Hofman, V. 2003. Biodiesel fuel: NDSU Extension Service. February. North Dakota State University, Fargo, USA, Goodfellow, J. 2010. Biofuel production from animal fats: A north American perspective. http://worldrenderers. org/11.pdf.
Kim, Y. J., Y. S. Ryou, J. T. Chang, J. H. Yun and T. Y. Yeon. 1999. Spraying and combustion characteristics of heavy oil in the gun type burner for hot air heater. Journal of the Korean Society for Agricultural Machinery 24:107-114 (In Korean, with English abstract).

Kim, Y. J., Y. S. Ryou, K. C. Kang, K. J. Lee and J. H. Yun. 2000. Combustion qualities of waste tire oil substituting light oil for greenhouse heating. Journal of the Korean Society for Agricultural Machinery 25:481-488 (In Korean, with English abstract).

Kim, Y. J., Y. K. Kang, K. C. Kang and Y. S. Ryou. 2008. Fuel qualities of different biodiesels in the gun type burner. Journal of Biosystems Engineering 33:124-129 (In Korean, with English abstract).

Kim, Y. J., S. H. Park, S. K. Kim and D. H. Im. 2010. Characteristics of paddy operations with biodiesel fuelled tractor. Proceedings of XVII ${ }^{\text {th }}$ World Congress of the International Commission of Agricultural Engineering (CIGR). Quebec, Canada.

Korea Institute of Energy Research. 2011. Manufacturing Processes of Biodiesel and Practice of Quality Control Management. $6^{\text {Th }}$ Technological Workshop. Bioenergy Core Technology Research Center (In Korean)

Lee, J. S. 2004. Commercialization status and prospects of biodiesel. Journal of Structure 33:45-49 (In Korean, with English abstract)

Ministry of Agriculture and Forestry. 2006. Development of Technology for the practical use of biodiesel fuel as a fuel of the agricultural diesel engine. Final Research Report. Chonbuk National University. Korea.

Prankl, H, H. Schaufler, H. Lampel, J. Zierfub, A. Burgsteiner and P. Prinz-Hufnagel. 2006. Engine Tests. FJ-BLT Wieselburg. Austria.

Wilson, A. 2003. Biodiesel: a cleaner, greener fuel for the 21st century. Environmental Building News 12:1-9. 